\title{
ANALISIS PERBANDINGAN FAKTOR-FAKTOR PENENTU PERCEIVED RISK PADA KONSUMEN ROKOK RINGAN DAN REGULAR \\ (Studi Kasus pada Mahasiswa Universitas Atmajaya Yogyakarta)
}

\author{
Indra Setiawan \\ Universitas AtmaJaya Yogyakarta \\ P. Didit Krisnadewara \\ Universitas AtmaJaya Yogyakarta
}

\begin{abstract}
This research was aimed at confirming a model of perceived risk developed by Oglethorpe (1994) on cigarette product. The prime determinant variables in the model were severity of outcome and probability of outcome, with five additional variables including availability, catastrophic potential, reversibility, controllability, and dreadedness. Furthermore, perceived risk model of two groups of cigarette product consumers, light cigarette smokers and regular cigarette smokers, were put into comparison. Structural Equation Modelling was applied and assisted by AMOS 3.6 software. The results indicated that prime variable is still a determinant for perceived risk. Examination of proposed additional variables indicated that only availability, reversibility, and dreadedness influenced outcome of probability, while severity of outcome was only influenced by catastrophic potential. This developed model of perceived risk has high level of compatibility with the data sample. In addition, the whole variables also formed latent variable by using examination of validity (convergent and discriminant validity) and reliability (construct reliability and extracted variance). The result of this research is also in line with the previous researchs result that light cigarette smokers have lower perceived risk than regular cigarette smokers do.
\end{abstract}

Keywords: structural equation modelling, perceived risk, regular cigarette smokers, light cigarrette smokers.

\section{Pendahuluan}

Perilaku konsumen melibatkan risiko oleh karena tindakan apapun dari seorang konsumen menghasilkan konsekuensi-konsekuensi yang tidak dapat diantisipasi dengan kepastian, konsep dari risiko yang dirasakan oleh konsumen (consumer's perceived risk) atau biasa disebut juga sebagai risiko yang dirasa (perceived risk), telah diterima sebagai sebagai suatu unsur yang utama dalam pengambilan keputusan konsumen (Bauer,1960 dalam Oglethorpe dan Monroe, 1994). Inti sari dari konsep tersebut adalah bahwa konsumen merasa berbagai jenis risiko dan persepsi-persepsi mereka mempengaruhi pengambilan keputusan dan perilaku mereka, pada umumnya dalam wujud beberapa macam strategi pengurangan risiko.

Perceived risk merupakan satu dari dua bidang dalam perilaku keputusan konsumen yang berhubungan dengan bagaimana konsumen memahami dan membuat keputusan tentang produk yang berisiko (Oglethorpe dan Monroe, 1994). Pernyataan tesebut sejalan dengan pendapat bahwa penelitian mengenai risiko akan sesuai apabila diterapkan pada produk dengan tingkat 
keterlibatan konsumen yang tinggi (Dowling dan Staling, 1994). Salah satu produk dengan tingkat keterlibatan konsumen yang tinggi yaitu rokok.

Menurut pandangan umum masyarakat, rokok merupakan salah satu contoh produk yang dianggap berbahaya / beresiko bagi kesehatan dan keselamatan. Hal ini didukung pula dengan adanya fakta, bahwa konsumsi tembakau dunia ternyata dapat membunuh satu orang setiap detiknya. Saat ini di dunia terdapat 4,9 juta kematian setiap tahunnya dimana 70 persen di antaranya terjadi di negara berkembang. Data Depkes dan Organisasi Kesehatan Dunia (WH0) dalam kampanye Hari Tanpa Tembakau Dunia, yang jatuh pada 31 Mei menyebutkan penggunaan tembakau menyebabkan penyakit dan kematian menyebabkan sebanyak $22,6 \%$ dari 3320 kematian di Indonesia. Tembakau juga menyebabkan 9,8\% kematian karena penyakit paru kronik dan emfisema dan 5\% kasus stroke di Indonesia. Asap rokok mengandung 4.000 bahan kimia dan 43 di antaranya penyebab kanker. Lebih dari 70.000 artikel telah membuktikan secara tuntas bahwa konsumsi tembakau dan paparan terhadap asap tembakau berbahaya bagi kesehatan. Bukti cukup kuat tersebut menyatakan bahwa tembakau sebagai penyebab kanker mulut, tenggorokan, lambung, pankreas, hati, ginjal, ureter, kandung kemih, mulut rahim, dan sumsum tulang. Wanita yang merokok mungkin mengalami penurunan atau penundaan kemampuan hamil, sedangkan pada pria akan meningkatkan risiko impotensi sebesar 50\% (www.depkes.go.id, 2004).

Salah satu jenis rokok yang beredar di Indonesia adalah sigaret mesin (SM). Pasar rokok sigaret mesin (SM) di Indonesia terbagi menjadi dua yaitu reguler dan ringan (mild slim). Perkembangan rokok ringan sangat pesat, ditandai dengan berkembangnya banyak merek yang dikeluarkan oleh produsen rokok, bahkan salah satu produsen sampai mengeluarkan 3 merek untuk melayani pasar tersebut. Tentu saja perkembangan rokok ringan tidak terlepas dari tumbuhnya pasar di kategori tersebut. Hal ini tidak lêpas dari persepsi konsumen bahwa rokok ringan merupakan rokok sehat, sehingga dapat merokok dengan jumlah yang sama dengan perokok reguler bahkan lebih.

Penelitian tentang persepsi terhadap rokok ringan (Kozlowski et al.., 1998) menemukan bahwa 20 - 40\% perokok rokok ringan percaya bahwa rokok dengan label rendah tar, rendah nikotin, atau light tersebut dapat menurunkan risiko dari masalah kesehatan. Lebih jauh Etter et al. (2003) menyimpulkan hal yang sesuai dengan penelitian (Kozlowski et al., 1998) bahwa rokok ringan mempunyai risiko yang lebih rendah dalam perkembangan penyakit kanker paru-paru dibandingkan rokok reguler. Dengan demikian menyebabkan perokok rokok regular mengambil pilihan untuk beralih ke rokok ringan daripada harus berhenti merokok.

Penelitian ini mencoba untuk membandingkan antara konsumen (perokok) rokok ringan dan konsumen (perokok) rokok regular jika dilihat dari bagaimana pengaruh faktor-faktor determinan terhadap risiko yang dirasakan konsumen pada produk tersebut. Variabel determinan yang digunakan dalam penelitian ini sama dengan variabel yang digunakan dalam penelitian Oglethorpe dan Monroe (1994) dan Etter et al. (2003).

\section{Tinjauan Pustaka}

Dalam penelitian tentang hubungan antara merokok dan kesehatan yang dirasa di Hong Kong. 6117 penduduk berbangsa Cina yang sehat (3053 laki-laki, 3064 perempuan), umur 25-74 tahun, dipilih secara acak dengan wawancara melalui telepon di Hong Kong dari tahun 1994 sampai 1996. Kesimpulan yang didapat adalah, mantan perokok terlihat mempunyai kesehatan yang dirasa buruk tetapi berhenti untuk jangka panjang akan mendapatkan manfaatnya. Secara keseluruhan perokok saat ini mempunyai kesehatan yang dirasa buruk dibandingkan perokok baru, tetapi risiko yang berlebihan terlihat pada laki-laki berumur tua. Kesehatan yang dirasa dari perokok mungkin mempunyai implikasi sebagai pendekatan yang dapat digunakan untuk berhenti merokok (Ho et al., 2002). Sedangkan dalam banyak penelitian dengan populasi masyarakat kulit putih menunjukkan bahwa perokok saat ini mempunyai kesehatan yang dirasa buruk dibandingkan dengan perokok baru (Ross dan Bird, 1994; Malmstrom et al., 1999; Manderbacka et al., 1999) 
atau bukan perokok (termasuk mantan dan tidak pernah merokok) (Bobak et al., 1998; Kawachi et al., 1999; Halpern-Felsher et al., 2003). Risiko yang dirasa di Spanyol juga tinggi untuk konsumen muda, tetapi rendah untuk konsumen yang terdidik (Antonanzas. et al., 2000). Penelitian di Prancis memberikan kesimpulan bahwa terdapat hubungan yang linier antara jumlah rokok yang digunakan dengan kesadaran terhadap penyakit kanker paru-paru. Dokter dan tenaga pendidik kesehatan harus menyadari bahwa banyak orang, terutama orang dewasa di Prancis, tidak mempersepsikan kondisi ini secara negatif (Sastre, et al., 1999). Penelitian tentang risiko yang dirasa diadakan di Delaware Valley, Pennsylvania, New Jersey, dan Philadelphia Amerika Serikat, dengan target populasi komunitas Asian Amerika, yaitu Cina, Korea, Vietnam, dan Kamboja, memberikan kesimpulan bahwa tingkat kesadaran tinggi terhadap risiko yang dirasa pada konsumen perempuan dan konsumen terdidik, konsumen bukan perokok dan mantan perokok, dan komunitas Cina dan Korea (Ma, et al., 2002).

Penelitian yang mengkaitkan antara kekebalan tubuh dengan pemakaian rokok pada 442 siswa sekolah menengah lanjutan menyarankan bahwa persepsi tentang kekebalan tubuh dapat menjadi prediksi untuk berhenti menggunakan tembakau dan mungkin mencerminkan kekebalan relatif yaitu penggunaan rokok ringan (Milam. et al., 2000).

Banyak perokok rokok ringan atau ultra ringan, memilih mengkonsumsi rokok tersebut untuk menurunkan risiko dari merokok atau langkah awal untuk berhenti. Mereka tidak sadar bahwa rokok ringan atau ultra ringan mempunyai jumlah tar dan nikotin yang sama dengan rokok reguler. Perokok rokok ringan yang menjadi sampel dalam penelitian ini lebih memilih untuk berhenti jika mereka tahu informasi ini. Keyakinan yang salah tentang merek rokok ringan menurunkan intensitas untuk berhenti merokok (Kozlowski et al., 1998). Etter et al. (2003) menyimpulkan dalam penelitiannya berkaitan dengan persepsi rokok ringan dan regular, bahwa perokok masih memilih rokok ringan karena mereka percaya rokok ringan lebih sehat atau tidak membuat ketergantungan.

Perceived risk merupakan satu dari dua bidang dalam perilaku keputusan konsumen yang berhubungan dengan bagaimana konsumen memahami dan membuat keputusan tentang produk yang berisiko (Oglethorpe dan Monroe, 1994). Munculnya model perceived risk atau risiko yang dirasa diawali oleh pendapat Bauer (1960 dalam Bettman, 1973) yang menyatakan bahwa perceived risk mempunyai dua struktur dimensional, yaitu ketidakpastian (uncertainty) dan konsekuensi yang tidak menguntungkan (adverse consequences). Pendapat ini kemudian dikembangkan oleh peneliti-peneliti mengenai risiko yang dirasa lainnya. Antara lain, Dowling (1986) dalam Oglethorpe dan Monroe (1994) mengasumsikan bahwa probabilitas hasil (probability of outcome\} dan keburukan hasil (severity of outcome\} merupakan fungsi dari risiko yang dirasa. Penelitian lain, menunjukkan bahwa untuk menjelaskan risiko yang dirasa, tidak cukup hanya dengan model sederhana (kemungkinan hasil dan keburukan hasil), tetapi variabel-variabel lain ternyata berpengaruh terhadap risiko yang dirasa (Oglethorpe dan Monroe, 1994) Controllability, availability, catastrophic potential, dreadedness dan reversibility merupakan variabel-variabel tambahan yang berpengaruh terhadap risiko yang dirasa. Kemudian oleh Oglethorpe dan Monroe (1994) dikembangkan sebuah model risiko yang dirasa (Gambar 1). Dalam model tersebut ditunjukkan bahwa terdapat tujuh determinan yang mempengaruhi risiko yang dirasakan oleh konsumen, meliputi: 1. kemungkinan hasil (probability of outcome); 2. keburukan hasil (severity of outcome), 3. ketersediaan (availability), 4. pengendalian (controllability), 5. ketakutan (dreadedness). 6. keterbalikan (reversibility), dan 7. potensi malapetaka (catastrophic potential). 


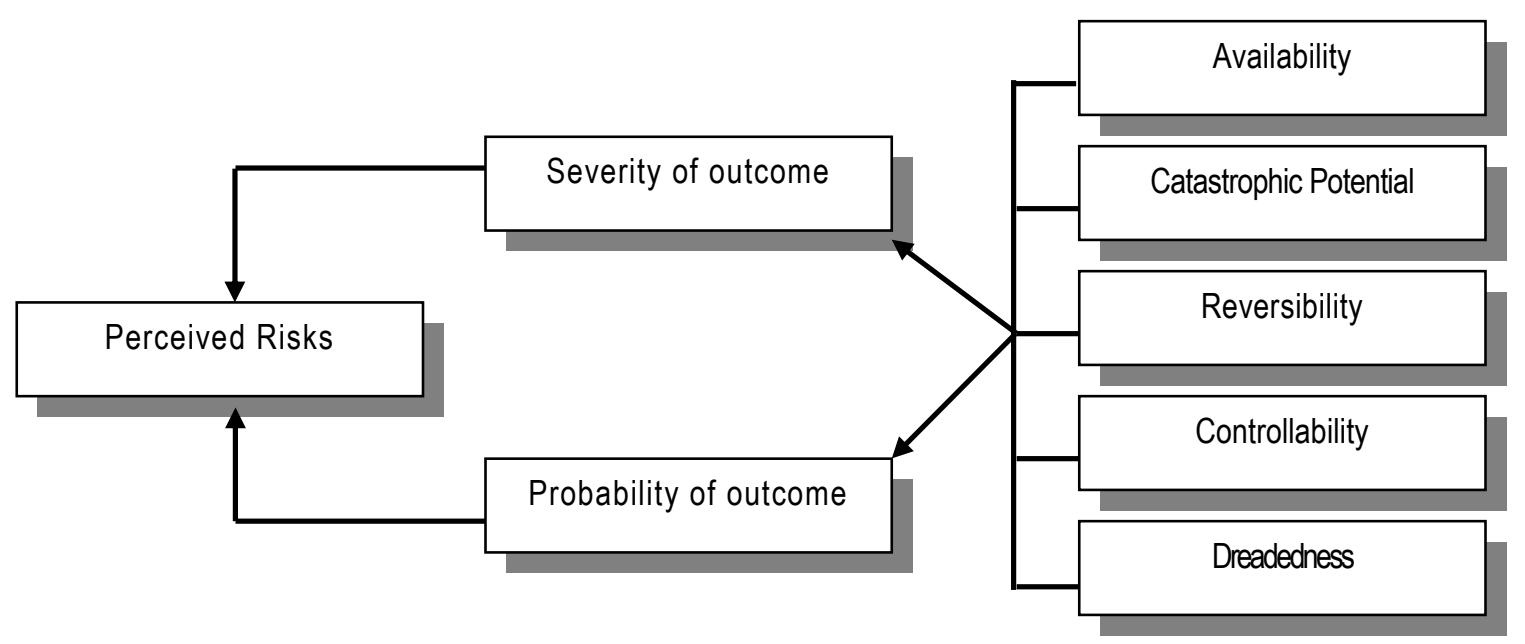

Sumber: Oglethorpe dan Monroe

(1994)

Gambar 1

Model Perceived Risk

\section{Pengembangan Model Hipotesis}

Model risiko yang dirasa seperti yang dikemukakan oleh Oglethorpe dan Monroe (1994) menggambarkan bahwa tujuh variabel bertindak sebagai determinan risiko yang dirasa sedangkan penelitian ini mencoba mengembangkan model penelitian dengan menambahkan variable dummy yang bersumber dari penelitian Etter et al. (2003). Dimana variable dummy tersebut membedakan risiko yang dirasa antara perokok rokok ringan dengan perokok rokok regular.

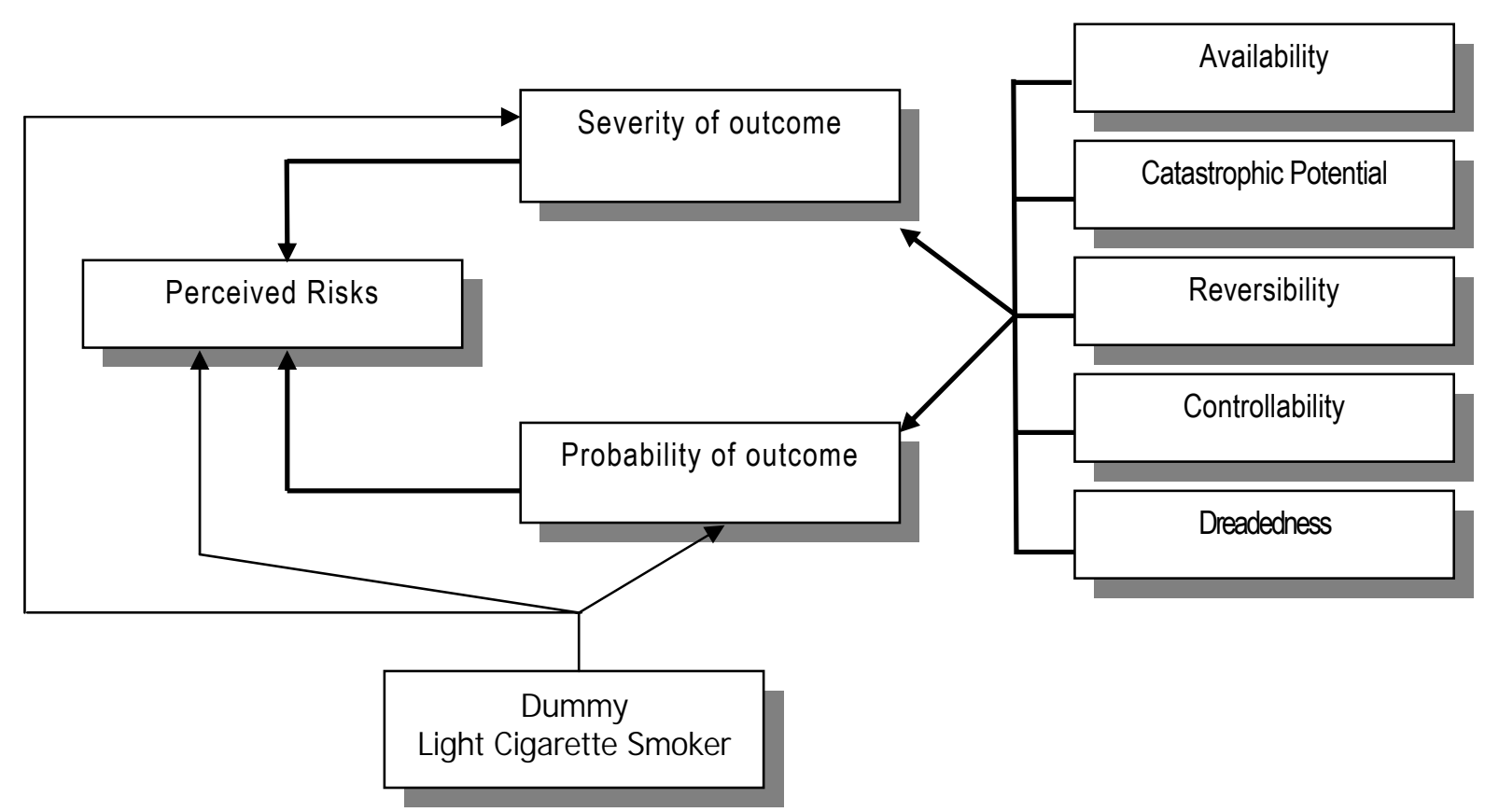

Gambar 2

Pengembangan Model Perceived Risk 
Berdasarkan pengembangan model tersebut maka dirumuskan hipotesis-hipotesis berikut ini:

Hipotesis 1 : Ketersediaan (availability) berpengaruh positif terhadap kemungkinan hasil (probability of outcome).

Hipotesis 2 : Ketersediaan (availability) berpengaruh positif terhadap keburukan hasil (severity of outcome).

Hipotesis 3 : Potensi malapetaka (catastrophic potential) berpengaruh positif terhadap terhadap kemungkinan hasil (probability of outcome).

Hipotesis 4 : Potensi malapetaka (catastrophic potential) berpengaruh positif terhadap keburukan hasil (severity of outcome).

Hipotesis 5 : Keterbalikan (reversibility) berpengaruh negatif terhadap kemungkinan hasil (probability of outcome).

Hipotesis 6 : Keterbalikan (reversibility) berpengaruh negatif terhadap keburukan hasil (severity of outcome).

Hipotesis 7 : Pengendalian (controllability) berpengaruh negatif terhadap kemungkinan hasil (probability of outcome).

Hipotesis 8 : Pengendalian (controllability) berpengaruh negatif terhadap keburukan hasil (severity of outcome).

Hipotesis 9 : Ketakutan (dreadedness) berpengaruh positif terhadap kemungkinan hasil (probability of outcome).

Hipotesis 10 : Ketakutan (dreadedness) berpengaruh positif terhadap keburukan hasil (severity of outcome).

Hipotesis 11 : Keburukan hasil (severity of outcome) berpengaruh positif terhadap risiko yang dirasa (perceived risk).

Hipotesis 12: Kemungkinan hasil (probability of outcome) berpengaruh positif terhadap risiko yang dirasa (perceived risk).

Hipotesis 13: Perokok rokok ringan berpengaruh negatif terhadap keburukan hasil (severity of outcome).

Hipotesis 14: Perokok rokok ringan berpengaruh negatif terhadap kemungkinan hasil (probability of outcome).

Hipotesis 15 : Perokok rokok ringan berpengaruh negatif terhadap risiko yang dirasa (perceived risk).

\section{Metoda Penelitian}

Pengambilan sampel yang digunakan adalah non probabilistic sampling, yaitu setiap elemen dari populasi tidak rnemiliki probabilitas yang sama untuk dipilih menjadi sampel (Sekaran, 2000). Teknik penentuan sampel non-probabilitas yang digunakan adalah purposive sampling yaitu memilih sampel dengan kriteria tertentu; (Cooper dan Schindler, 2003). Kriteria yang digunakan adalah mahasiswa Universitas Atmajaya Yogyakarta yang mempunyai kebiasaan merokok dengan rokok ringan ataupun regular.

Karena teknik analisis data yang digunakan adalah structural equation modeling, maka jumlah minimal sampel yang diambil sebesar 10 x jumlah variabel yaitu sekurangnya 90 sampel (Solimun, 2002).

\subsection{Definisi Operasional}

Penelitian ini mengadopsi instrumen pengukuran yang telah dikembangkan oleh peneliti sebelumnya. Namun demikian dalam penelitian ini dilakukan pengujian kembali validitas dan reliabilitas dari instrumen pengukuran tersebut. Instrumen pengukuran terdiri dari delapan konstruk yang dioperasionalisasikan, yaitu probability of outcome, severity of outcome, controllability, availability, catastrophic potential, dreadednes, reversibilitv dan perceived risk. Untuk perbandingan maka diberikan variabel dummy sebagai variabel kontrol. Uraian definisi operational dan teknik pengukuran untuk masingmasing instrumen adalah sebagai berikut 
Availability diukur melalui tiga item pertanyaan dengan dua skala kategori dan satu skala likert. Pertanyaan variabel ini diadopsi dan dikembangkan dan penelitian Oglethorpe dan Monroe (1994), dengan contoh '"How easy is it for you to imagine the negative consequence assiciated with the use of this product?"

Catastrophic Potential diukur melalui tiga item pertanyaan dengan dua skala kategori dan satu skala likert. Pertanyaan untuk variabel ini diadopsi dan dikembangkan dari penelitian Oglethorpe dan Monroe (1994), dengan contoh "When an individual uses this product, the negative consequence affects a number of people, not only the individual who uses it".

Reversibility diukur melalui tiga item pertanyaan dengan satu skala likert dan dua skala 100 point. Pertanyaan untuk variabel ini diadopsi dan dikembangkan dari penelitian Oglethorpe dan Monroe (1994), yaitu "To What extent is the negative consequence associated with the use of this product permanent".

Controllability diukur melalui tiga item kuesioner dengan skala 100 point. Pertanyaan dalam kuesioner diadopsi dan dikembangkan dalam penelitian Oglethorpe dan Monroe (1994), yaitu "Given that people use this product, to what extent can they control, or influence, the likelihood of suffering the associated negative consequence.

Dreadedness diukur melalui tiga item pertanyaan dengan dua skala kategori dan satu skala likert. Pertanyaan untuk variabel ini diadopsi dan dikembangkan dari penelitian Oglethorpe dan Monroe (1994), yaitu "Is this negative consequence one that you react to emotionally that is, with dread or fear?"

Severity of outcome diukur melalui tiga item kuesioner dengan dua skala kategori dan satu skala likert. Pertanyaan dalam kuesioner diadopsi dan dikembangkan dalam penelitian Oglethorpe dan Monroe (1994), yaitu "How severe is the negative concequence associated with using this product?"

Probability of outcome diukur dengan satu skala likert dan dua skala 10 point. Pertanyaan diadopsi dan dikembangkan dari penelitian Oglethorpe dan Monroe"(1994), sebagai contoh "The chances are great that the use of this product will result in the associated negative consequence"

Perceived risk diukur melalui tiga item pertanyaan dengan satu skala kategori, satu skala likert, dan satu skala 10 point. Pertanyaan untuk variabel ini diadopsi dan dikembangkan dari penelitian Oglethorpe dan Monroe (1994), yaitu "To what extent is a person who uses this product taking a risk?"

Dummy Variable tentang karakteristik perokok dalam penelitian ini terbagi atas dua kategori yaitu perokok rokok ringan (Light Cigarette Smoker) dan perokok rokok regular (Reguler Cigarette Smoker). Kategori 1 untuk perokok rokok ringan dan kategori 0 untuk perokok rokok regular. Data diambil dari pertanyaan terbuka "Secara umum, merek rokok yang Anda konsumsi adalah?"

\section{Analisis Data}

\subsection{Analisis Outlier}

Analisis untuk menemukan outlier ini menggunakan Mahalanobis distance. Hasil analisis Mahalanobis distance didapatkan bahwa konsumen 94; 33; 69; dan 67, mempunyai jarak sebesar 78,023; 60,753; 56,411; dan 56,246 dari titik tengah dengan p1 dan p2 yang sangat rendah, sebesar 0,000. Hal ini menunjukkan bahwa keempat konsumen tersebut memberikan jawaban yang sangat ekstrim pada beberapa pertanyaan, sehingga dapat dikatakan sebagai outlier yang selanjutnya perlu untuk dihilangkan(Byrne, 2001). Dari analisis ini didapatkan jumlah missing data sebanyak 6 konsumen dan 4 konsumen termasuk outlier, sehingga jumlah keseluruhan data yang dapat diolah sebanyak 102 responden.

\subsection{Analisis Normalitas Data}

Analisis distribusi normalitas data dilakukan dengan melihat nilai skewness dan kurtosis. Nilai skewness menunjukkan kecondongan dari distribusi data, sedangkan kurtosis menunjukkan kesimetrisan distribusi data. Asumsi distribusi normalitas data menggunakan probabilitas 5 persen satu sisi didapatkan batas critical ratio (C.R.) sebesar 1,645.

Mardia's coefficient of multivariate kurtosis digunakan untuk melihat normalitas pada keseluruhan variabel observasi. Hasil analisis mendapatkan nilai Mardia's coefficient of 
multivariate kurtosis sebesar 9,547 dengan C.R. sebesar 1,312. Dengan demikian secara keseluruhan variabel observasi dapat dikatakan normal.

\subsection{Pengujian Overall Model Fit}

Sebelum melakukan analisis model struktural dan model measurement, perlu dilihat apakah model secara keseluruhan merepresentasikan keseluruhan hubungan sebab akibat. Terdapat tiga tipe goodness-of-fit yang biasa digunakan yaitu Absolut Fit Measures, Incremental Fit Measures, dan Parsimony Fit Measure. Absolut Fit Measure diwakili oleh $X^{2}$ dan significant level, Root Mean Square Error of Approximation (RMSEA). Incremental Fit Measures menggunakan pengukuran Tucker-Lewis Index (TLI). Terakhir, Parsimonious Fit Measures menggunakan pengukuran Comparative Fit Index (CFI).

$X^{2}$ (Chi-Square) merupakan indikator untuk pengukuran overal fit. $X^{2}$ bersifat sangat sensitif terhadap besarnya sampel yang digunakan. Model dipandang sesuai dengan datanya jika mempunyai nilai yang relatif kecil dengan tingkat signifikansi lebih besar dari 0,05 (Hair et al., 1998). RMSEA merupakan pengukuran goodness of fit yang dapat diharapkan bila model diestimasi dalam populasinya. Nilai RMSEA yang lebih kecil dari 0,05 merupakan indeks yang diterima dengan baik menunjukkan sebuah close fit dari model berdasarkan degree of freedom. TLI dan CFI merupakan sebuah alternatif yang membandingkan model yang diuji dengan baseline model. Nilai yang direkomendasikan baik adalah lebih besar dari 0,95 (Hair et al., 1998).

Dari hasil analisis didapatkan nilai Chi-square sebesar 284,964 dengan degree of freedom sebesar 251 memberikan tingkat signifikansi sebesar 0,069 lebih besar dari tingkat signifikansi yang direkom(Hair et al., 1998). Dengan demikian matrik input yang sebenarnya dengan matrik input yang diprediksi tidak berbeda secara statistis. Tingkat RMSEA hasil penelitian sebesar 0,037 dengan nilai yang direkomendasikan kurang dari 0,05. Nilai TLI dan CFI masing masing adalah sebesar 0,979 dan 0,982 dengan tingkat yang direkomendasikan lebih besar dari 0,95. Tabel berikut menunjukkan hasil yang didapatkan dan nilai yang direkomendasikan.

Tabel 1

Perhitungan Pengukuran Goodness of Fit Model

\begin{tabular}{cccc}
\hline $\begin{array}{c}\text { Indikator Goodness of } \\
\text { Fit }\end{array}$ & $\begin{array}{c}\text { Tingkat Kesesuaian } \\
\text { yang direkomendasikan }\end{array}$ & $\begin{array}{c}\text { Hasil Pengukuran } \\
\text { Model Penelitian }\end{array}$ & Evaluasi Hasil \\
\hline$X^{2}$ (Chi-Square) & Diharapkan kecil & 284,964 & Relatif Baik \\
P & $\geq 0,050$ & 0,069 & Baik \\
RMSEA & $\leq 0,050$ & 0,037 & Baik \\
TLI & $\geq 0,950$ & 0,979 & Baik \\
CFI & $\geq 0,950$ & 0,982 & Baik \\
\hline
\end{tabular}

\subsection{Pengujian Measurement Model}

Sebelum dilakukan analsis SEM maka dilakukan pengujian measuremet model yaitu pengujian validitas dan reliabilitas dari setiap item pertanyaan dalam membentuk setiap konstruk. Analisis validitas konstruk, yaitu validitas diskriminan dan validitas konvergen, dilakukan dengan menggunakan confirmatory factor analysis, sedangkan reliabilitas dengan menggunakan Construct Reliability dan Variance Extracted.

RMSEA sebesar 0,$541 ; 1,000$; dan 0,000. Hasil ini sesuai dengan rekomendasi yang disarankan yaitu Probabilitas $X^{2}$ lebih besar dari 0,05 . Nilai CFI yang direkomendasikan baik adalah lebih besar dari 0,95. Sedangkan nilai RMSEA yang disarankan adalah kurang dari 0,05 (Hair et al., 1998). Lebih jauh, seperti terlihat dalam Tabel 5, nilai standardized loading dari keseluruhan variabel observasi sangat tinggi dan signifikan. Hasil ini menunjukkan bahwa variabel observasi memenuhi validitas diskriminan, yaitu variabel observasi mewakili konstruknya masing-masing. Analisis validitas konvergen menunjukkan kelima konstruk mempunyai korelasi rendah diantara konstruk tersebut. Hal ini ditunjukkan dengan tidak terdapatnya nilai korelasi yang sama dengan 
satu. Dengan demikian hasil ini memenuhi validitas konstruk, yaitu variabel observasi telah dapat mewakili konstruknya masing-masing dan kelima konstruk tidak saling berhubungan.

Tabel 2

Perhitungan Pengukuran Goodness of Fit CFA

\begin{tabular}{cccc}
\hline $\begin{array}{c}\text { Indikator Goodness of } \\
\text { Fit }\end{array}$ & $\begin{array}{c}\text { Tingkat Kesesuaian } \\
\text { yang } \\
\text { direkomendasikan }\end{array}$ & $\begin{array}{c}\text { Hasil Pengukuran } \\
\text { Model Penelitian }\end{array}$ & Evaluasi Hasil \\
\hline P & $\geq 0,050$ & 0,541 & Baik \\
RMSEA & $\leq 0,050$ & 0,000 & Baik \\
CFI & $\geq 0,950$ & 1,000 & Baik \\
\hline
\end{tabular}

Analisis Reliabilitas dilakukan dengan menggunakan Construct Reliability dan Variance Extracted. Tabel 7 menunjukkan hasil perhitungan Construct Reliability dan Variance Extracted untuk masing-masing konstruk. Dari hasil ini tidak terdapat nilai Construct Reliability yang lebih kecil dari 0,7 dan Variance Extracted yang lebih kecil dari 0,5. Dengan demikian dapat dikatakan bahwa keseluruhan item pertanyaan mempunyai reliabilitas yang tinggi untuk membentuk konstruknya.

Tabel 3

\section{Pengujian Reliabilitas}

\begin{tabular}{lcc}
\hline & Construct & Variance \\
\hline $\mathrm{K}$ & 0,806 & 0,581 \\
$\mathrm{~K}$ & 0,829 & 0,617 \\
$\mathrm{~K}$ & 0,885 & 0,721 \\
$\mathrm{~K}$ & 0,928 & 0,812 \\
$\mathrm{~K}$ & 0,755 & 0,507 \\
$\mathrm{~K}$ & 0,832 & 0,623 \\
$\mathrm{~K}$ & 0,919 & 0,790 \\
$\mathrm{~K}$ & 0,906 & 0,763 \\
\hline
\end{tabular}

\subsection{Pengujian Model Struktural}

Setelah analisis terhadap overall model dan measurement model didapatkan hasil yang baik, maka langkah selanjutnya dapat dilakukan pengujian terhadap hipotesis struktural model. Indikator yang digunakan untuk menguji hipotesis yang diajukan adalah dengan membandingkan nilai Critical Ratio (C.R.) hitung dengan nilai C.R. tabel. Tingkat signifikansi yang digunakan adalah sebesar 5 persen satu sisi dengan nilai C.R. tabel sebesar 1,645 (Hair et al., 1989). Tabel 4 memberikan evaluasi terhadap tingkat signifikansi dari setiap hipotesis penelitian. 
Tabel 4

Evaluasi Critical Ratio Hipotesis Penelitian

\begin{tabular}{|c|c|c|c|c|c|}
\hline $\mathrm{Ha}$ & Hubungan antar Variabel & Estimasi & $\begin{array}{c}\text { Critical } \\
\text { Ratio }\end{array}$ & Standardized & Evaluasi \\
\hline $\mathrm{H} 1$ & $\begin{array}{c}\text { availability berpengaruh positif terhadap probability } \\
\text { of outcome }\end{array}$ & 0.884 & 2.552 & 0.657 & Signifikan $(+)$ \\
\hline $\mathrm{H} 2$ & $\begin{array}{l}\text { availability berpengaruh positif terhadap severity of } \\
\text { outcome }\end{array}$ & 0.240 & 1.163 & 0.225 & $\begin{array}{l}\text { Tidak } \\
\text { Signifikan }\end{array}$ \\
\hline $\mathrm{H} 3$ & $\begin{array}{c}\text { catastrophic potential berpengaruh positif terhadap } \\
\text { terhadap probability of outcome }\end{array}$ & -0.424 & -1.282 & -0.341 & $\begin{array}{c}\text { Tidak } \\
\text { Signifikan }\end{array}$ \\
\hline $\mathrm{H} 4$ & $\begin{array}{c}\text { catastrophic potential berpengaruh positif terhadap } \\
\text { severity of outcome }\end{array}$ & 0.617 & 3.139 & 0.626 & Signifikan $(+)$ \\
\hline $\mathrm{H} 5$ & $\begin{array}{l}\text { reversibility berpengaruh negatif terhadap } \\
\text { probability of outcome }\end{array}$ & -0.274 & -1.976 & -0.346 & Signifikan (-) \\
\hline $\mathrm{H} 6$ & $\begin{array}{l}\text { reversibility berpengaruh negatif terhadap severity } \\
\text { of outcome }\end{array}$ & -0.073 & -0.827 & & $\begin{array}{l}\text { Tidak } \\
\text { Signifikan }\end{array}$ \\
\hline $\mathrm{H} 7$ & $\begin{array}{c}\text { controllability berpengaruh negatif terhadap } \\
\text { probability of outcome }\end{array}$ & 0.037 & 0.315 & & $\begin{array}{l}\text { Tidak } \\
\text { Signifikan }\end{array}$ \\
\hline $\mathrm{H} 8$ & $\begin{array}{l}\text { controllability berpengaruh negatif terhadap } \\
\text { severity of outcome }\end{array}$ & -0.025 & -0.341 & & $\begin{array}{l}\text { Tidak } \\
\text { Signifikan }\end{array}$ \\
\hline $\mathrm{H} 9$ & $\begin{array}{c}\text { dreadedness berpengaruh positif terhadap } \\
\text { probability of outcome }\end{array}$ & 0.785 & & 0.586 & Signifikan $(+)$ \\
\hline H10 & $\begin{array}{c}\text { dreadedness berpengaruh positif terhadap severity } \\
\text { of outcome }\end{array}$ & 0.226 & & 0.213 & $\begin{array}{l}\text { Tidak } \\
\text { Signifikan }\end{array}$ \\
\hline H11 & $\begin{array}{l}\text { severity of outcome berpengaruh positif terhadap } \\
\text { perceived risk }\end{array}$ & & 4.673 & 0.425 & Signifikan $(+)$ \\
\hline $\mathrm{H} 12$ & $\begin{array}{c}\text { probability of outcome berpengaruh positif } \\
\text { terhadap perceived risk }\end{array}$ & & 6.239 & 0.585 & Signifikan $(+)$ \\
\hline $\mathrm{H} 13$ & $\begin{array}{c}\text { Perokok rokok ringan berpengaruh negative } \\
\text { terhadap severity of outcome }\end{array}$ & -0.177 & -1.919 & -0.109 & Signifikan (-) \\
\hline H14 & $\begin{array}{l}\text { Perokok rokok ringan berpengaruh negative } \\
\text { terhadap probability of outcome }\end{array}$ & -0.451 & -3.625 & -0.220 & Signifikan (-) \\
\hline H15 & $\begin{array}{c}\text { Perokok rokok ringan berpengaruh negative } \\
\text { terhadap perceived risk }\end{array}$ & -0.227 & -2.198 & -0.105 & Signifikan (-) \\
\hline
\end{tabular}

Hipotesis 1 merupakan pengujian untuk mengetahui apakah terdapat pengaruh positif variabel availability terhadap probability of outcome. Hasil analisis menunjukkan bahwa $t$ hitung lebih besar dari pada tabel (signifikan positif). Dengan demikian variabel availability mempunyai pengaruh positif terhadap probability of outcome. Hal ini sesuai dengan penelitian Oglethorpe. Dari hasil ini dapat disimpulkan bahwa kenaikan tingkat ketersediaan ingatan akan konsekuensi negatif akibat merokok dalam diri konsumen akan menimbulkan pengaruh berupa kenaikan tingkat kemungkinan terjadinya hasil negatif akibat merokok pada diri konsumen.

Hipotesis 2 merupakan pengujian untuk mengetahui apakah terdapat pengaruh positif variabel availability terhadap severity of outcome. Hasil analisis menunjukkan bahwa $t$ hitung lebih kecil dari pada $t$ tabel (tidak signifikan). Dengan demikian variabel availability tidak mempunyai pengaruh terhadap severity of outcome. Dari hasil ini dapat disimpulkan bahwa tingkat ketersediaan ingatan akan konsekuensi negatif akibat merokok dalam diri konsumen tidak mempengaruhi tingkat keburukan hasil negatif akibat merokok pada diri konsumen.

Hipotesis 3 merupakan pengujian untuk mengetahui apakah terdapat pengaruh positif variabel catastrophic potential terhadap probability of outcome. Hasil analisis menunjukkan bahwa $t$ hitung lebih kecil dari pada $t_{\text {tabel }}$ (tidak signifikan). Dengan demikian variabel catastrophic potential tidak mempunyai pengaruh terhadap severity of outcome. Dari hasil ini dapat disimpulkan bahwa tingkat potensi malapetaka akibat merokok yang dipersepsikan oleh konsumen tidak mempengaruhi tingkat kemungkinan terjadinya hasil negatif akibat merokok pada diri konsumen. 
Hipotesis 4 merupakan pengujian untuk mengetahui apakah terdapat pengaruh positif variabel catastrophic potential terhadap severity of outcome. Hasil analisis menunjukkan bahwa t hitung lebih besar dari pada $t$ tabel (signifikan positif). Dengan demikian variabel catastrophic potential mempunyai pengaruh terhadap severity of outcome. Dari hasil ini dapat disimpulkan bahwa kenaikan tingkat potensi malapetaka akibat merokok yang dipersepsikan konsumen menimbulkan pengaruh berupa kenaikan tingkat keburukan hasil negatif akibat merokok pada diri konsumen.

Hipotesis 5 merupakan pengujian untuk mengetahui apakah terdapat pengaruh negatif variabel reversibility terhadap probability of outcome. Hasil analisis menunjukkan bahwa $t$ hitung lebih besar dari pada $t$ tabel (signifikan negatif). Dengan demikian variabel reversibility mempunyai pengaruh negatif terhadap probability of outcome. Dari hasil ini dapat disimpulkan bahwa kenaikan tingkat keterbalikan yang dipersepsikan oleh konsumen akan menimbulkan pengaruh berupa penurunan tingkat kemungkinan terjadinya hasil negatif akibat merokok pada diri konsumen.

Hipotesis 6 merupakan pengujian untuk mengetahui apakah terdapat pengaruh negatif variabel reversibility terhadap severity of outcome. Hasil analisis menunjukkan bahwa $t$ hitung lebih kecil dari pada $t$ tabel (tidak signifikan). Dengan demikian variabel reversibility tidak mempunyai pengaruh terhadap severity of outcome. Dari hasil ini dapat disimpulkan bahwa tingkat keterbalikan yang dipersepsikan oleh konsumen tidak mempengaruhi tingkat keburukan hasil negatif akibat merokok pada diri konsumen.

Hipotesis 7 merupakan pengujian untuk mengetahui apakah terdapat pengaruh negatif variabel controllability terhadap probability of outcome. Hasil analisis menunjukkan bahwa $t$ nitung lebih kecil dari pada $t$ tabel (tidak signifikan). Dengan demikian variabel controllability tidak mempunyai pengaruh terhadap probability of outcome. Dari hasil ini dapat disimpulkan bahwa tingkat kemampuan pengendalian terhadap konsekuensi negatif akibat merokok pada diri konsumen tidak mempengaruhi tingkat kemungkinan terjadinya hasil negatif akibat merokok pada diri konsumen.

Hipotesis 8 merupakan pengujian untuk mengetahui apakah terdapat pengaruh positif variabel controllability terhadap severity of outcome. Hasil analisis menunjukkan bahwa $t$ hitung lebih kecil dari pada $t$ tabel (tidak signifikan). Dengan demikian variabel controllability tidak mempunyai pengaruh terhadap severity of outcome. Dari hasil ini dapat disimpulkan bahwa tingkat kemampuan pengendalian terhadap konsekuensi negatif akibat merokok pada diri konsumen tidak mempengaruhi tingkat keburukan hasil negatif akibat merokok pada diri konsumen.

Hipotesis 9 merupakan pengujian untuk mengetahui apakah terdapat pengaruh positif variabel dreadedness terhadap probability of outcome. Hasil analisis menunjukkan bahwa $t$ nitung lebih besar dari pada $t$ tabel (signifikan positif). Dengan demikian variabel dreadedness mempunyai pengaruh positif terhadap probability of outcome. Dari hasil ini dapat disimpulkan bahwa kenaikan tingkat ketakutan konsumen akan bahaya konsekuensi negatif akan menimbulkan pengaruh berupa kenaikan tingkat kemungkinan terjadinya hasil negatif akibat merokok pada diri konsumen.

Hipotesis 10 merupakan pengujian untuk mengetahui apakah terdapat pengaruh positif variabel dreadedness terhadap severity of outcome. Hasil analisis menunjukkan bahwa $t$ hitung lebih kecil dari pada $t$ tabel (tidak signifikan). Dengan demikian variabel dreadedness tidak mempunyai pengaruh terhadap severity of outcome Dari hasil ini dapat disimpulkan bahwa tingkat ketakutan konsumen terhadap konsekuensi negatif tidak mempengaruhi tingkat keburukan hasil negatif akibat merokok pada diri konsumen.

Hipotesis 11 merupakan pengujian untuk mengetahui apakah terdapat pengaruh positif variabel severity of outcome terhadap perceived risk. Hasil analisis menunjukkan bahwa $t$ nitung lebih besar dari pada $t$ tabel (signifikan positif). Dengan demikian variabel severity of outcome mempunyai pengaruh positif terhadap perceived risk. Dari hasil ini dapat disimpulkan bahwa 
kenaikan tingkat keburukan hasil negatif akibat merokok pada diri konsumen akan menimbulkan pengaruh berupa kenaikan tingkat risiko kesehatan dan keselamatan yang dirasakan konsumen.

Hipotesis 12 merupakan pengujian untuk mengetahui apakah terdapat pengaruh positif variabel probability of outcome terhadap perceived risk. Hasil analisis menunjukkan bahwa $t$ hitung lebih besar dari pada $t$ tabel (signifikan positif). Dengan demikian variabel probability of outcome mempunyai pengaruh positif terhadap perceived risk. Dari hasil ini dapat disimpulkan bahwa kenaikan tingkat kemungkinan terjadinya hasil negatif akibat merokok pada diri konsumen akan menimbulkan pengaruh berupa kenaikan tingkat risiko kesehatan dan keselamatan yang dirasakan konsumen.

Hipotesis 13 merupakan pengujian untuk mengetahui apakah perokok rokok ringan mempunyai pengaruh yang berbeda dengan perokok rokok regular terhadap severity of outcome. Hasil analisis menunjukkan bahwa $t$ nitung lebih besar dari pada $t$ tabel (signifikan negatif). Dengan demikian terdapat perbedaan pengaruh antara light cigarette smoker dengan regular cigarette smoker terhadap severity of outcome. Hasil analisis lebih lanjut menyimpulkan bahwa perokok rokok ringan mempunyai persepsi tingkat keburukan hasil negatif akibat merokok pada diri konsumen yang lebih rendah dibandingkan perokok rokok regular.

Hipotesis 14 merupakan pengujian untuk mengetahui apakah perokok rokok ringan mempunyai pengaruh yang berbeda dengan perokok rokok regular terhadap probability of outcome. Hasil analisis menunjukkan bahwa $t$ nitung lebih besar dari pada $t$ tabel (signifikan negatif). Dengan demikian terdapat perbedaan pengaruh antara light cigarette smoker dengan regular cigarette smoker terhadap probability of outcome. Hasil analisis lebih lanjut menyimpulkan bahwa perokok rokok ringan mempunyai persepsi tingkat kemungkinan terjadinya hasil negatif akibat merokok pada diri konsumen yang lebih rendah dibandingkan perokok rokok regular.

Hipotesis 15 merupakan pengujian untuk mengetahui apakah perokok rokok ringan mempunyai pengaruh yang berbeda dengan perokok rokok regular terhadap perceived risk. Hasil analisis menunjukkan bahwa $t$ hitung lebih besar dari pada $t$ tabel (signifikan negatif). Dengan demikian terdapat perbedaan pengaruh antara light cigarette smoker dengan regular cigarette smoker terhadap perceived risk. Hasil analisis lebih lanjut menyimpulkan bahwa perokok rokok ringan mempunyai persepsi tingkat risiko yang dirasa akibat merokok pada diri konsumen yang lebih rendah dibandingkan perokok rokok regular.

\section{Simpulan}

Berdasarkan hasil analisis menunjukkan bahwa model penelitian ini sesuai dengan data observasi. Hal ini ditunjukkan dengan beberapa pengukuran dalam pengujian Overall Model Fit yang memenuhi persyaratan yang direkomendasikan, yaitu oleh $x^{2}$, significant level, RMSEA, TLI, dan CFI masing-masing 284,964; 0,069; 0,037; 0,979; dan 0,982. Hal ini mengindikasi bahwa model penelitian ini sesuai dengan populasinya. Pengujian measurement model juga menunjukkan hasil yang baik. Validitas konstruk variabel eksogen diuji dengan menggunakan Confirmatory Factor Analysis. Reliabilitas diuji dengan menggunakan Construct Reliability dan Variance Extracted. Pengujian CFA menunjukkan nilai Probabilitas $X^{2}$ (Chi-Square), CFI, dan RMSEA masing-masing sebesar 0,541; 1,000; dan 0,000. Lebih jauh nilai standardized loading menunjukkan hasil yang tinggi dan signifikan.

Pengujian terhadap model penelitian ini dapat disimpulkan bahwa ketersediaan ingatan dalam diri konsumen akan mempengaruhi tingkat kemungkinan terjadinya konsekuensi negatif akibat merokok. Namun ketersediaan ingatan dalam diri konsumen tidak mempengaruhi tingkat keburukan konsekuensi negatif akibat merokok. Temuan lain didapatkan bahwa semakin banyak orang yang terkena pengaruh negatif dari merokok tidak mempengaruhi tingkat kemungkinan terjadinya konsekuensi negatif tersebut pada konsumen tetapi akan meningkatkan keburukan konsekuensi negative konsumen. 
Semakin tinggi keyakinan konsumen untuk membalikkan konsekuensi negatif yang terjadi akan semakin rendah pengaruh kemungkinan terjadinya konsekuensi negatif pada diri konsumen, namun tidak mengubah tingkat keburukan konsekuensi negatif tersebut pada konsumen. Sedangkan tingkat ketakutan konsumen akan bahaya konsekuensi negatif yang meningkat akan menaikkan tingkat pengaruh kemungkinan terjadinya konsekuensi negatif pada diri konsumen.

Hipotesis 10 Dari hasil ini dapat disimpulkan bahwa tingkat ketakutan konsumen terhadap konsekuensi negatif tidak mempengaruhi tingkat keburukan konsekuensi negatif tersebut pada konsumen.

Semakin besar tingkat keburukan konsekuensi negatif pada konsumen akan memperbesar tingkat pengaruh risiko kesehatan dan keselamatan yang dirasakan konsumen. Konsumen yang merokok dengan rokok ringan mempunyai persepsi tingkat keburukan konsekuensi negatif merokok yang lebih rendah dibandingkan perokok rokok regular.

Secara umum, hasil dari pengujian tersebut dapat diambil kesimpulan bahwa variabel Severity of Outcome dan Probability of Outcome mempengaruhi risiko yang dirasa (Perceived Risk), dalam arti semakin tinggi tingkat kemungkinan risiko terjadinya hasil negatif dan semakin tinggi tingkat keburukan hasil tersebut akan membuat semakin tinggi tingkat risiko yang dirasa oleh konsumen. Dari nilai koefisien standardized terlihat bahwa Probability of Outcome mempunyai pengaruh terhadap Perceived Risk yang lebih tinggi dibandingkan dibandingkan Severity of Outcome.

Pengujian terhadap variabel tambahan yang diusulkan yaitu variabel availability, catastrophic potential, reversibility, controllability, dan dreadedness menunjukkan bahwa variabel availability, reversibility dan dreadedness yang mempengaruhi probability of outcome, sedangkan Severity of Outcome hanya dipengaruhi oleh catastrophic potential. Dengan demikian dapat diambil kesimpulan bahwa ketersediaan ingatan, keterbalikan, dan ketakutan dalam diri konsumen akan mempengaruhi kemungkinan terjadinya konsekuensi negatif akibat merokok, dan semakin banyak orang yang terkena pengaruh negatif dari merokok maka tingkat keburukan hasil negatif tersebut akan meningkat pada konsumen.

Pengujian perbedaan antara perokok rokok ringan dan rokok regular menunjukkan bahwa terdapat perbedaan penilaian dalam variabel Perceived Risk, Probability of Outcome, dan Severity of Outcome. Dengan demikian dapat disimpulkan bahwa perokok rokok ringan lebih rendah dalam mempersepsikan tingkat risiko yang dirasa, tingkat kemungkinan terjadinya hasil negatif, dan besarnya tingkat keburukan hasil negatif jika dibandingkan dengan perokok rokok regular.

\section{DAFTAR PUSTAKA}

Antonanzas, F., W. K. Viscusi, Rovira Jr., Francisco J.B., Portillo, F., Carvalho, I. (2000), "Smoking Risks in Spain: Part I-Perception of Risks to the Smoker," Journal of Risk and Uncertainty, 21:2/3, Hal 161186.

Bobak, M., Pikhart, H., Hertzman, C., Rose, R., dan Marmot, M. (1998), "Socioeconomic Factors, Perceived Control and Factors Self-reported Health in Russia. A cross-sectional survey," Social Science \& Medicine, 47, Hal 269-279.

Byrne, B.M. (2001), Structural Equation Modeling, Basic Concepts, Aplications, and Programming, Lawrence Erlbaum Associates, Inc.

Cooper, D. dan Schindler, P. (2003), Business Research Method, International Edition, McGraw-Hill, Inc, New York. 
Dowling, G.R. and Staeling, R. (1994), "A Model of Perceived Risk and Intended Risk-Handling Activity," Journal of Consumer Research, Vol. 21, No.1, pp. 119-134.

Etter, J., Kozlowski, L.T., dan Perneger, T.V. (2003), "What Smokers Believe about Light and Ultralight Cigarettes," Preventive Medicine 36, 92-98

Hair, J.F.Jr., Anderson, R.E., Tatham, R.L., Black, W.C. (1998), Multivariate Data Analysis, Fifth Edition, Prentice Hall, Inc.

Halpern-Felsher, B.L., Biehl, M., dan Rubinstein, M.L. (2003), "Perceived Risks and Benefit of Smoking: Differences Between Adolecents Who Have and Have Not Smoke," Journal of Adolecent Health Vol. 32, No. 2.

Ho, S.Y., Tai Hing Lam, T.H., Fielding, R., dan Janus, E.D. (2003), "Smoking and Perceived Health in Hong Kong Chinese," Social Science \& Medicine 57, Hal 1761-1770

Kawachi, I., Kennedy, B. P., dan Glass, R. (1999), "Social Capital and Self-rated Health: A Contextual Analysis," American Journal of Public Health, 89, Hal 1187-1193.

Kozlowski, L.T., Goldberg, M.E., Yost, B.A., White, E.L., Sweeney, C.T., Pillitteri, J.L. (1998), "Smokers' Misperceptions of Light and Ultra-Light Cigarettes May Keep Them Smoking," American Journal of Preventive Medicine Vol. 15, No. 1.

Ma, G.X., Tan, Y., Feeley, R.M., Thomas, P. (2002), "Perceived Risks of Certain Types of Cancer and Heart Disease Among Asian American Smokers and Non-Smokers," Journal of Community Health, Vol. 27, No. 4.

Malmstrom, M., Sundquist, J., dan Johansson, S. E. (1999), "Neighborhood Environment and Self-reported Health Status: A Multilevel Analysis," American Journal of Public Health, 89, Hal 1181-1186.

Manderbacka, K., Lundberg, O., dan Martikainen, P. (1999), "Do Risk Factors and Health Behaviors Contribute to Selfratings of Health?" Social Science \& Medicine, 48, Hal 1713-1720.

Milam, J.E., Sussman, S., Ritt-Olson A., dan Dent, C.W. (2000), "Perceived Invulnerability and Cigarette Smoking Among Adulescents," Addictive Behaviors, Vol. 25, No. 1, Hal 71-80,

Oglethorpe, Janet E. dan Monroe, Kent B. (1994), "Determinants of Perceived Health and Safety Risks of Selected Hazardous Products and Activities," The Journal of Consumer Affairs, Vol. 28, No. 2, 1994, Hal $326-346$

Ross, C. E. dan Bird, C. E. (1994), "Sex Stratification Health Lifestyle: Consequences for Men's and Women's Perceived Health," Journal of Health and Social Behavior, 35, Hal 161-178.

Sastre, M.T.M., Mullet, E., dan Sorum, P.C. (1999), "Relationship between Cigarette Dose and Perceived Risk of Lung Cancer," Preventive Medicine 28, Hal 566-571.

Sekaran, U. (2000), Research Methodsfor Business, United Stated of America: John Willey \& Sons, Inc.

Solimun (2002), Structural Equation Modeling Lisrel dan Amos, Penerbit Universitas Negeri Malang, Malang. 
Umar, H. (2000), Riset Pemasaran dan Perilaku Konsumen, Jakarta: Jakarta Business Research Center (JBRC).

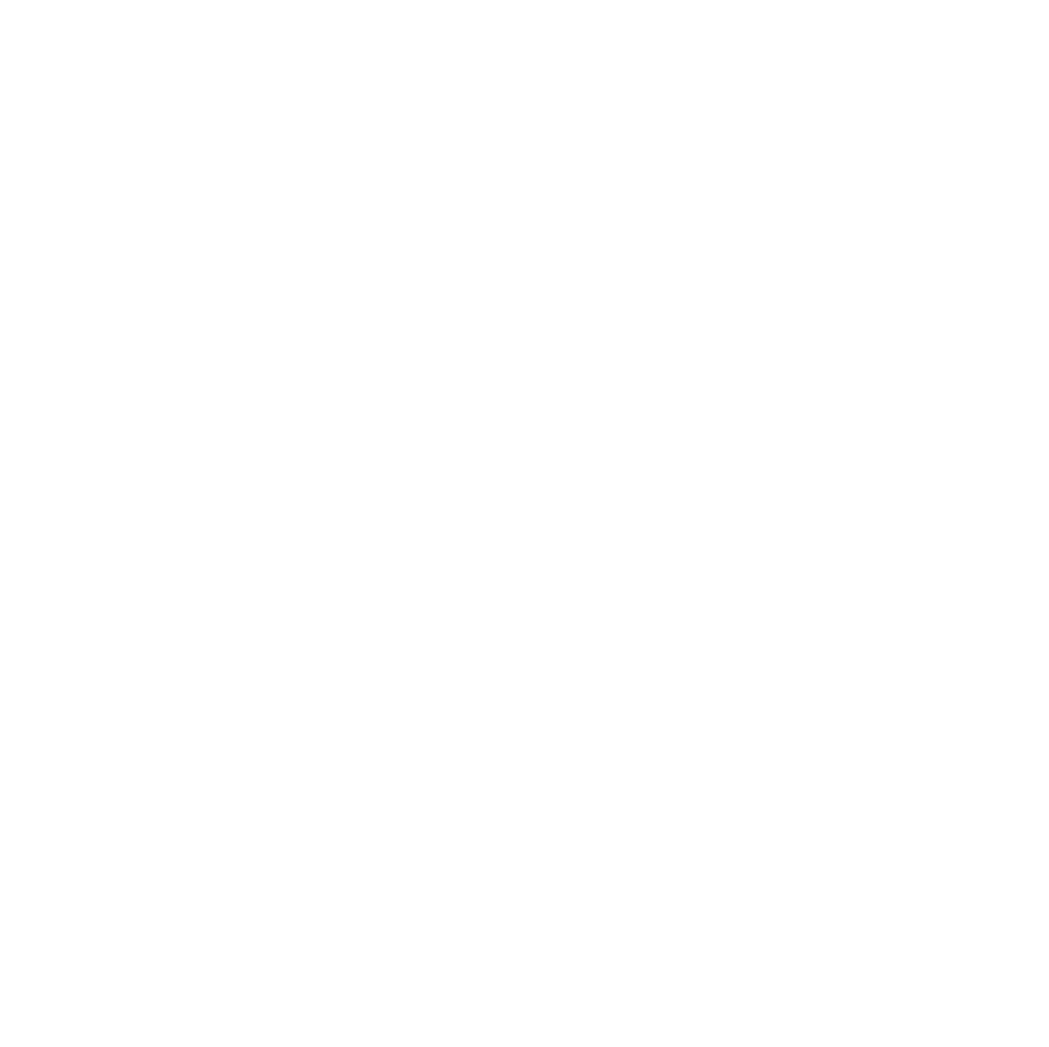

